\title{
Quality of life assessment in WHOQOL-BREF domains amongst home care clients in selected regions of the Czech Republic
}

\section{Ocena jakości życia osób korzystających z opieki domowej na podstawie domen ankiety WHOQOL-BREF w wybranych regionach Czech}

\author{
Helena Kisvetrová1,A,C-F, Lucie Martincová1,A-C,E,F , Sárka Vévodová2, ${ }^{2, C-F}$, Jiří Vévoda ${ }^{2, A, C-F}$ \\ ${ }^{1}$ Center for Research and Science, Faculty of Health Sciences, Palacký University, Olomouc, Czech Republic \\ ${ }^{2}$ Department of Humanities and Social Sciences, Faculty of Health Sciences, Palacký University, Olomouc, Czech Republic \\ A - research concept and design; $\mathrm{B}$ - collection and/or assembly of data; $\mathrm{C}$ - data analysis and interpretation; \\ $D$ - writing the article; $E$ - critical revision of the article; $F$ - final approval of article
}

Address for correspondence

Helena Kisvetrová

E-mail:helena.kisvetrova@upol.cz

\section{Conflict of interests}

None declared

\section{External funds}

Supported by Ministry of Health of the Czech Republic, grant no. 16-28628A

Received on November 18, 2016

Revised on May 23, 2017

Accepted on June 25, 2017
DOI

10.17219/pzp/75486

Copyright

C 2017 by Wroclaw Medical University

This is an article distributed under the terms of the

Creative Commons Attribution Non-Commercial License (http://creativecommons.org/licenses/by-nc-nd/4.0/)

\begin{abstract}
Background. Population ageing is a topical phenomenon that is going to accelerate. This elicits an increasing interest in the quality of life (QoL) of the ageing population in home care. The present paper strives to ascertain how home care clients assess QoL and to find the relation between QoL and the age of the respondents.

Objectives. The aim of the study was to investigate how older adults, clients of home care, assess QoL in the domains defined by the WHOQOL-BREF. A secondary aim was to ascertain whether there is a correlation between the QoL assessment in each of the domains and the age of the respondents.

Material and methods. Cross-sectional study, WHOQ0L-BREF questionnaire, 121 home care clients from 2 Czech regions.

Results. Totally, 43\% respondents assessed their overall Q0L as good/very good. The lowest satisfaction was in "sex life" (mean 2.0), "negative feelings" (mean 2.6) and "capacity for work" (mean 2.6). The most positive assessment was in "access to health services" (mean 3.6) and "support from friends" (mean 3.5). № correlation between the QoL assessment in individual domains and age was found $(r=-0.022$ to -0.153 ; $p>0.05)$.

Conclusions. Nearly half of Czech respondents assessed QoL as good or very good and their satisfaction with health was most often neutral. No significant correlation between the age of the respondents and the QoL assessment in particular domains of the WHOQOL-BREF questionnaire was demonstrated. The respondents were least satisfied with their sex life. This means that nurses should educate clients about ways to overcome barriers in their sex life.
\end{abstract}

Key words: quality of life, WHOQOL-BREF, home care, older adult 


\section{Streszczenie}

Wprowadzenie. Starzenie się populacji to współczesne zjawisko, które przybiera na sile. Powoduje to, że zwiększa się zainteresowanie jakością życia (QoL - Quality of Life) osób starszych objętych opieką domową. Niniejsza praca jest próbą odpowiedzi na pytanie, jak oceniają jakość swojego życia osoby korzystające z opieki domowej oraz czy istnieje związek pomiędzy jakością życia a wiekiem respondentów.

Cel pracy. Analiza oceny jakości życia według domen ankiety WHOQOL-BREF (kwestionariusz oceny jakości życia wg WHO, wersja skrócona) przeprowadzonej wśród osób starszych objętych opieką domową. Próbowano ponadto ustalić, czy ocena QoL w poszczególnych domenach zależy od wieku respondentów.

Materiał i metody. Badanie przekrojowe, WH0Q0L-BREF, 121 osób pozostających pod opieką domową wybranych spośród mieszkańców 2 regionów Czech.

Wyniki. Łącznie 43\% respondentów oceniło ogólnie jakość swojego życia jako dobrą/bardzo dobrą. Najniższy poziom satysfakcji odnotowano w kategoriach: „życie seksualne" (średnia 2,0), "negatywne odczucia”" (średnia 2,6) i „zdolność do pracy” (średnia 2,6). Najbardziej pozytywnie oceniono "dostęp do usług medycznych” (średnia 3,6) oraz „wsparcie ze strony przyjaciół” (średnia 3,5). Nie zaobserwowano zależności pomiędzy oceną QoL w poszczególnych domenach a wiekiem ankietowanych (od $r=-0,022 \mathrm{do}-0,153 ; p>0,05)$.

Wnioski. Niemal połowa czeskich respondentów oceniła jakość swojego życia jako dobrą albo bardzo dobrą, a zadowolenie ze stanu zdrowia było w większości przypadków umiarkowane. Badanie nie wykazało istotnego związku pomiędzy wiekiem respondentów a oceną QoL w poszczególnych domenach kwestionariusza WHOQ0L-BREF. Ankietowani byli najmniej zadowoleni ze swojego życia seksualnego. Oznacza to, że osoby sprawujące opiekę pielęgniarską powinny wskazywać swoim pacjentom sposoby na przełamywanie barier w życiu seksualnym.

Słowa kluczowe: jakość życia, WHOQOL-BREF, opieka domowa, osoba starsza

\section{Background}

Ageing of the population is a common long-lasting demographic trend apparent in most European countries, including the Czech Republic. It is the result of a decreasing birth rate or its stagnation at a low level respectively, combined with a decrease in morality rates. The age preference index in the Czech Republic reached 113.3 by the end of 2012. ${ }^{1}$ This fact gives rise to an increasing interest in studying QoL of the ageing population. ${ }^{2}$ When assessing QoL at an older age, people consider functional abilities and general health, social networks, social support and living conditions important. ${ }^{3-6}$ Age is also given by some studies as a factor influencing QoL. ${ }^{7-8}$ Maintaining good QoL is only possible when an older adult is independent, may fulfill his/her social roles, stays active and perceives his/her life as meaningful. It is also important to maintain his/her psychological well-being and positive thinking, sex life, availability of leisure time activities, having something to look forward to in future and financial independence. ${ }^{9}$ Assessing QoL in the ageing population helps to identify the needs of this social group..$^{10}$

The aim of the study was to investigate how older adults, clients of home care, assess QoL in the domains defined by the WHOQOL-BREF. A secondary aim was to ascertain whether there is a correlation between the QoL assessment in each of the domains and the age of the respondents.

\section{Material and methods}

A cross-sectional study using the Czech version of WHOQOL-BREF was conducted. ${ }^{11}$ The official Czech version of the questionnaire was used in the study after registration at the Czech WHOQOL center.

\section{Sample}

The target group consisted of older adults living in a home environment who were provided with home care in 2 Czech regions: Zlín and Uherské Hradiště. The inclusion criteria were age over 50 years and a signed informed consent. Exclusion criteria were severe sensory impairment (hearing, vision) and MMSE test value $<20$ points. Home care agencies, charity nursing care and regional Red Cross branches were addressed in the Zlín and Uherské Hradiště regions.

\section{Ethical approval}

The entire study was conducted in accordance with the 1975 Helsinki Declaration, as revised in 2004 and 2008. The study was approved by the Ethics Committee of the Faculty of Health Sciences, Palacký University, Olomouc, the Czech Republic. Informed consent to participate was obtained for the study contents, purposes, and protocols, data confidentiality and anonymity procedures, and participants' freedom to discontinue the study was explained. All subjects signed informed consent before enrollment.

\section{Instrument}

The WHOQOL-BREF questionnaire is one of the most common generic questionnaires focusing on QoL which can be used in different cultures for international or regional comparison and correlation in relation to various 
socio-demographic characteristics. ${ }^{12}$ Although it was not developed specifically for an older population, its applicability in older adult populations has been reported. Good psychometric results were proved in a heterogeneous group of older adults. Its usability in a population of older individuals, including older adults in a community environment, has been confirmed by previous research. ${ }^{13-15}$ The WHOQOL-BREF is relatively short (26 items) and is divided into four domains. The domain Physical Health is comprised of 7 items about everyday activities and work capability, energy and tiredness, mobility, dependence on medical care, sleep, pain and discomfort. The Psychological domain looks at satisfaction with oneself, negative feelings, concentration, enjoyment of life, acceptance of bodily appearance and meaning of life. The domain Social Relationships asks about support from friends, sex life and personal relationships. The Environment domain deals with access to health services and transportation, personal safety, safety in the environment, information availability, financial situation and leisure activities.

\section{Data collection}

The study sample was selected based on the availability in the location (Zlín and Uherské Hradiště regions) and willingness of the organizations providing home care to take part in the research. Six institutions providing home care agreed to participate in the Zlín and Uherské Hradiště regions. Two hundred seven potential study participants met the inclusion criteria and were informed about the aims of our study. A research nurse and a home care nurse visited them in their homes, presented the research and handed the questionnaire form to the respondents. Some of them chose to fill in the questionnaire in a structured interview with the research nurse. Most of the clients preferred filling in the questionnaire by themselves.

\section{Statistical analysis}

Descriptive statistics was used to process the collected data. Each item of the WHOQOL-BREF was described using the Likert scale $1-5$, where 5 meant the best assessment of QoL (however, in items Q3, Q4 and Q26 the scale is inverted). The mean, standard deviation (SD) and median were calculated for each item. Gross scores were calculated for each of the questionnaire domains and were subsequently transformed into a scale of 4-20. To calculate mean score and medians, the recommended methodology by Dragomirecká was used in items Q3, Q4 and Q26 with the inverted scale, i.e. the higher the score, the better QoL. ${ }^{16}$ Using the Kolmogorov-Smirnov test, the gross score distribution for each domain was tested for normal distribution. To test the correlation between the assessments in each of the domains and the age of respondents, the Spearman correlation analysis was used. All tests were performed with a significance level of $\mathrm{p} \leq 0.05$. The statistical processing was carried out using IBM SPSS Statistics 22.0.

\section{Results}

The questionnaire was completed by 121 respondents ( $58.5 \%$ out of 207 respondents included in the study). The mean age was $77.7 \pm 8.9$ years; only $5.8 \%$ were younger than 65 years. The demographic data is in Table 1 .

Table 1. Demographic data

Tabela 1. Dane demograficzne

\begin{tabular}{lcc|}
\multicolumn{3}{c}{ Respondents $(\mathrm{n}=121)$} \\
\hline $\begin{array}{l}\text { Age } \\
\text { (years) }\end{array}$ & median (min-max) & $79(51-93)$ \\
\hline Gender & mean \pm SD & $77.7 \pm 8.9$ \\
$\mathrm{n}(\%)$ & male & $44(36.4)$ \\
\hline & female & $77(63.6)$ \\
\hline Education & elementary school & $43(35.6)$ \\
$\mathrm{n}(\%)$ & vocational school & $39(32.2)$ \\
& secondary school & $31(25.6)$ \\
\hline & University & $8(6.6)$ \\
Marital status & married & $50(41.3)$ \\
$\mathrm{n}(\%)$ & divorced & $11(9.1)$ \\
& widowed & $55(45.5)$ \\
\hline Social conditions & single & $5(4.1)$ \\
$\mathrm{n}(\%)$ & lives with relatives & $25(20.7)$ \\
& lives with a partner & $45(37.2)$ \\
& lives alone & $51(42.1)$ \\
\hline
\end{tabular}

$\mathrm{n}$ - number; SD - standard deviation.

\section{Assessment of items in the domains}

Totally, 52 (43\%) respondents assessed their Overall QoL as good or very good but only $26(21 \%)$ as poor or very poor. In the $2^{\text {nd }}$ question, 28 (23\%) respondents gave a positive assessment of their General Health (good or very good) and 41 (34\%) were not satisfied with their health (poor or very poor). The frequency of answers in each item is listed in Table 2 . The most positive assessment was recorded in the domain "Environment" (mean 13.0). The respondents were least satisfied with QoL in the domain of "Physical Health" (mean 11.4).

The highest satisfaction was recorded in items: access to health services (mean 3.6), support from friends (mean 3.5 ) and condition of living place (mean 3.5). On the other hand, the lowest satisfaction was reported in items: capacity for work (mean 2.6), negative feelings (mean 2.6) and sex life (mean 2.0).

In the domain "Physical Health", the respondents were most satisfied with how much medical treatment 
Table 2. Results of all items in WHOQOL-BREF

Tabela 2. Wyniki kwestionariusza WHOQOL-BREF

\begin{tabular}{|c|c|c|c|c|c|c|}
\hline \multirow{2}{*}{ Item No. } & \multirow{2}{*}{ Item } & \multicolumn{5}{|c|}{ Likert scale, n (\%) } \\
\hline & & 1 & 2 & 3 & 4 & 5 \\
\hline Q1 & overall QoL'1 & $5(4)$ & $21(17)$ & $43(36)$ & $46(38)$ & $6(5)$ \\
\hline Q2 & general health satisfaction ${ }^{2}$ & $7(6)$ & $34(28)$ & $52(43)$ & $27(22)$ & $1(1)$ \\
\hline Q3 & pain and discomfort ${ }^{3}$ & $6(5)$ & $29(24)$ & $44(36)$ & $40(33)$ & $2(2)$ \\
\hline Q4 & dependence on medical treatment ${ }^{3}$ & $4(3)$ & $28(23)$ & $44(36)$ & $37(31)$ & $8(7)$ \\
\hline Q5 & enjoyment of life ${ }^{3}$ & $3(2)$ & $30(25)$ & $45(37)$ & $35(29)$ & $8(7)$ \\
\hline Q6 & meaning of life ${ }^{3}$ & $6(5)$ & $30(25)$ & $42(34)$ & $36(30)$ & $7(6)$ \\
\hline Q7 & concentration $^{3}$ & $4(3)$ & $34(28)$ & $58(48)$ & $20(17)$ & $5(4)$ \\
\hline Q8 & personal safety ${ }^{3}$ & $2(2)$ & $25(20)$ & $67(55)$ & $19(16)$ & $8(7)$ \\
\hline Q9 & environment $^{3}$ & $0(0)$ & $12(10)$ & $52(43)$ & $44(36)$ & $13(11)$ \\
\hline Q10 & energy and tiredness ${ }^{4}$ & $8(7)$ & $41(34)$ & $36(30)$ & $31(25)$ & $5(4)$ \\
\hline Q11 & acceptance of bodily appearance 4 & $2(2)$ & $26(21)$ & $55(45)$ & $31(26)$ & $7(6)$ \\
\hline Q12 & financial situation ${ }^{4}$ & $10(8)$ & $29(24)$ & $44(36)$ & $31(26)$ & $7(6)$ \\
\hline Q13 & information availability ${ }^{4}$ & $0(0)$ & $21(17)$ & $40(33)$ & $54(45)$ & $6(5)$ \\
\hline Q14 & leisure activities ${ }^{4}$ & $14(11)$ & $33(27)$ & $37(31)$ & $30(25)$ & $7(6)$ \\
\hline Q15 & mobility ${ }^{1}$ & $16(13)$ & $29(24)$ & $49(40)$ & $25(21)$ & $2(2)$ \\
\hline Q16 & sleep ${ }^{2}$ & $5(4)$ & $33(27)$ & $36(30)$ & $39(32)$ & $8(7)$ \\
\hline Q17 & daily living activities ${ }^{2}$ & $8(7)$ & $32(26)$ & $53(44)$ & $26(21)$ & $2(2)$ \\
\hline Q18 & capacity for work² & $18(15)$ & $38(31)$ & $42(35)$ & $21(17)$ & $2(2)$ \\
\hline Q19 & satisfaction with oneself² & $8(7)$ & $26(21)$ & $54(45)$ & $29(24)$ & $4(3)$ \\
\hline Q20 & personal relationships ${ }^{2}$ & $2(2)$ & $17(14)$ & $50(41)$ & $44(36)$ & $8(7)$ \\
\hline Q21 & sex life ${ }^{2}$ & $58(48)$ & $16(13)$ & $38(31)$ & $7(6)$ & $2(2)$ \\
\hline Q22 & support from friends ${ }^{2}$ & $0(0)$ & $8(7)$ & $54(44)$ & $51(42)$ & $8(7)$ \\
\hline Q23 & condition of living place ${ }^{2}$ & $0(0)$ & $17(14)$ & $40(33)$ & $53(44)$ & $11(9)$ \\
\hline Q24 & access to health services ${ }^{2}$ & $1(1)$ & $10(8)$ & $39(32)$ & $60(50)$ & $11(9)$ \\
\hline Q25 & transportation ${ }^{2}$ & $2(2)$ & $23(19)$ & $52(43)$ & $35(29)$ & $8(7)$ \\
\hline Q26 & negative feelings ${ }^{5}$ & $10(8)$ & $47(39)$ & $47(39)$ & $16(13)$ & $1(1)$ \\
\hline
\end{tabular}

${ }^{1}$ Likert scale (1: very poor, 2: poor, 3: neither poor nor good, 4: good, 5: very good);

${ }^{2}$ Likert scale (1: very dissatisfied, 2: dissatisfied, 3: neither satisfied nor dissatisfied, 4: satisfied, 5: very satisfied);

${ }^{3}$ Likert scale (1: not at all, 2: a little, 3: a moderate amount, 4: very much, 5: an extreme amount);

${ }^{4}$ Likert scale (1: not at all, 2: a little, 3: moderately, 4: mostly, 5: completely):

${ }^{5}$ Likert scale (1: never, 2: seldom, 3: quite often, 4: very often, 5: always).

they need to function in daily life (mean 3.1) but least satisfied with capacity for work (mean 2.6) and with their mobility (mean 2.7). In the domain "Psychological", the participants were most satisfied with life enjoyment (mean 3.12). The least positive was the assessment of frequent negative feelings, such as bad mood, despair, anxiety and depression (mean 2.6), ability to concentrate (mean 2.9) and acceptance of physical appearance (mean 2.9). In the domain "Social Relationships", the participants were least satisfied with their sex life (mean 2.0). In the domain "Environment", the most positive assessment was recorded in access to health services (mean 3.6). Contrarily, the respondents were least satisfied with opportunities for leisure activities (mean 2.9). The mean scores in each domain are listed in Table 3.

\section{The effect of age on QoL assessment in each domain}

The study results did not confirm any statistically significant correlation between the age of the respondents and QoL assessment in particular domains defined in the WHOQOL-BREF questionnaire $(r=-0.022$ to $r=-0.153$; $\mathrm{p}=2.094$ to $\mathrm{p}=0.815$ ). The values of each of the domains are listed in Table 4.

\section{Discussion}

The presented study results show that nearly half of the respondents (43\%) assessed QoL as good or very good and their satisfaction with health was most often (43\%) neutral (neither satisfied nor dissatisfied). Only 23\% reported 
Table 3. Results in WHOOQL -BREF items per domain

Tabela 3. Wyniki kwestionariusza WHOQOL-BREF wg domen

\begin{tabular}{|c|c|c|c|c|c|}
\hline Domain & Item & Item name & Mean \pm SD & Median & Min-max \\
\hline \multirow{8}{*}{ I. Physical health } & $\mathrm{Q}^{1}$ & pain and discomfort & $3.04 \pm 0.92$ & 3 & $1-5$ \\
\hline & Q41 & dependence on medical treatment & $3.10 \pm 0.97$ & 3 & $1-5$ \\
\hline & Q10 & energy and tiredness & $2.86 \pm 1.00$ & 3 & $1-5$ \\
\hline & Q15 & mobility & $2.73 \pm 0.98$ & 3 & $1-5$ \\
\hline & Q16 & sleep & $3.09 \pm 1.01$ & 3 & $1-5$ \\
\hline & Q17 & daily living activities & $2.84 \pm 0.90$ & 3 & $1-5$ \\
\hline & Q18 & capacity for work & $2.61 \pm 1.01$ & 3 & $1-5$ \\
\hline & Q5 & enjoyment of life & $3.12 \pm 0.94$ & 3 & $1-5$ \\
\hline \multirow{5}{*}{ II. Psychological } & Q6 & meaning of life & $3.06 \pm 0.98$ & 3 & $1-5$ \\
\hline & Q7 & concentration & $2.90 \pm 0.86$ & 3 & $1-5$ \\
\hline & Q11 & acceptance of bodily appearance & $2.90 \pm 0.86$ & 3 & $1-5$ \\
\hline & Q19 & satisfaction with oneself & $2.94 \pm 0.94$ & 3 & $1-5$ \\
\hline & Q26닌 & negative feelings & $2.59 \pm 0.85$ & 3 & $1-5$ \\
\hline \multirow{3}{*}{ III. Social relationships } & Q20 & personal relationships & $3.33 \pm 0.86$ & 3 & $1-5$ \\
\hline & Q21 & sex life & $2.00 \pm 1.08$ & 2 & $1-5$ \\
\hline & Q22 & support from friends & $3.50 \pm 0.73$ & 3 & $2-5$ \\
\hline \multirow{8}{*}{ IV. Environment } & Q8 & personal safety & $3.06 \pm 0.85$ & 3 & $1-5$ \\
\hline & Q9 & environment & $3.47 \pm 0.81$ & 3 & $2-5$ \\
\hline & Q12 & financial situation & $2.97 \pm 1.03$ & 3 & $1-5$ \\
\hline & Q13 & information availability & $3.38 \pm 0.81$ & 3 & $2-5$ \\
\hline & Q14 & leisure activities & $2.85 \pm 1.09$ & 3 & $1-5$ \\
\hline & Q23 & condition of living place & $3.47 \pm 0.84$ & 4 & $2-5$ \\
\hline & Q24 & access to health services & $3.57 \pm 0.80$ & 4 & $1-5$ \\
\hline & Q25 & transportation & $3.18 \pm 0.90$ & 3 & $1-5$ \\
\hline
\end{tabular}

${ }^{1}$ The Dragomirecká methodology was used to calculate mean scores and median with inverted scales ${ }^{17}$; SD - standard deviation.

Table 4. The gross score in the particular domains of the WHOQOL-BREF and correlation with the age of respondents

Tabela 4. Wynik brutto dla poszczególnych domen WHOQOL-BREF wraz z korelacją z wiekiem respondentów

\begin{tabular}{|c|c|c|c|c|}
\hline Domain & $\operatorname{Mean}^{1} \pm \mathrm{SD}$ & Median' & Min-max & $\begin{array}{l}\text { Correlation with age } \\
\text { Spearman r, p-value }\end{array}$ \\
\hline I. Physical health; points & $11.4 \pm 2.9$ & 11.4 & $5-18$ & $r=-0.153, p=0.094$ \\
\hline II. Psychological; points & $12.4 \pm 2.7$ & 12.0 & $5-20$ & $r=-0.130, p=0.154$ \\
\hline III. Social relationships; points & $11.8 \pm 2.4$ & 12.0 & $5-20$ & $r=-0.122, p=0.184$ \\
\hline IV. Environment; points & $13.0 \pm 2.4$ & 13.5 & $6-19$ & $r=-0.022, p=0.815$ \\
\hline
\end{tabular}

${ }^{1}$ Inverted scales was used in questions Q3, Q4 and Q26 in concordance with the Dragomirecká methodology ${ }^{17}$; SD - standard deviation.

they were satisfied with their health. No significant correlation was found between the age of the respondents and the QoL assessment in the particular domains defined in the WHOQOL-BREF questionnaire.

In a large international study with 11,830 participants from 23 countries, QoL was considered good or very good by $53 \%$ of respondents. Only $26 \%$ of respondents were neutral about their health and $50 \%$ were satisfied. ${ }^{12}$ An explanation of these differences may lie in age distribution and various diseases of the respondents. In the international study, the respondents were substan- tially younger (mean age $45 \pm 16$ years) than in our study (mean age $77.7 \pm 8.9$ years). Another factor influencing the more positive assessment of QoL was that half of the participants in the international study did not receive any medical care, whereas our participants were all home care clients.

On the other hand, QoL was assessed as good or very good by only $17 \%$ of the respondents in a Polish study. This might be due to the fact that $46 \%$ of the Polish respondents were aged 80 and older and most of them had chronic health problems. Among the participants 
who did not suffer from severe disease symptoms (pain, breathlessness, palpitation, unstable blood pressure), the assessment of QoL was twice as high. ${ }^{17}$

The results of the QoL assessment among the inhabitants of Chinese city communities show that, in concordance with our results, 39\% of the respondents were satisfied with their QoL. ${ }^{7}$ Fourty one per cent of the respondents were satisfied or very satisfied with their health and a neutral assessment of general health was reported by $44 \%$ of the respondents. The lower number of satisfied respondents in the presented study may reflect the fact that $78 \%$ of the Chinese respondents did not suffer from any chronic illness.

Our respondents were least satisfied with their sex life (very dissatisfied 48\%; mean score 2.0). Previous research has suggested that physical changes accompanying ageing do not necessarily lead to decreased sexual functions. A good physical and psychological condition, understanding and a positive attitude to sex in both partners make it possible to continue sexual activity at older age. Even the older generation considers intimate relationships important and refutes the stereotype about "asexual older adults". ${ }^{18-20}$ The participants in the recent study by Roney and Kazer commented that the expression of sexuality had changed due to the partner's health. Some identified less sexual frequency and spontaneity, while others stated that they were now more open with their sexual relationship. ${ }^{21}$ Skevington et al. state that only $8 \%$ of participants in their study were dissatisfied with their sex life, which may be explained by a lower mean age (45 years), with only $20 \%$ of the respondents over 60 years. ${ }^{12} \mathrm{Xia}$ et al. presented only $1 \%$ of very dissatisfied respondents, while $36 \%$ commented they were satisfied with their sex life. The results of the Chinese study could be biased due to the high percentage of participants who did not answer this question. ${ }^{7}$ Another reason, which was also apparent in a study by Chien et al., might be a clear reluctance of participants to talk about this intimate question with strangers. ${ }^{22}$ In this context, we must appreciate that all the participants in our study were willing to answer this question.

Very low satisfaction was recorded by our participants in the item capacity for work, where $15 \%$ were very dissatisfied (mean 2.6). The difference in international studies may again be explained by a higher age mean in comparison to a study by Skevington et al., where only $5 \%$ were very dissatisfied, or Xia et al., where only $0.3 \%$ were very dissatisfied and $47 \%$ were satisfied. ${ }^{7,12}$

The highest satisfaction amongst our respondents was ascertained in the items access to health services (mean 3.6; very satisfied or satisfied 59\%) and support from friends (mean 3.5; very satisfied or satisfied 49\%). In access to health services, Skevington et al. presented similar results (61\%) and higher satisfaction with support from friends (63\%). ${ }^{12}$ In the Chinese study, the participants assessed access to health services quite negatively. Only
$37 \%$ of the respondents were satisfied or very satisfied and $52 \%$ of participants were satisfied with support from friends. ${ }^{7}$ The results confirm that the overall high level of social support amongst patients in home care lowers negative feelings such as anxiety and depression and is a significant predictor of health-related QoL. ${ }^{23-24}$

Our study demonstrated no statistically significant correlation between the age of the respondents and QoL in the particular domains. The results might be influenced by the fact that the age range in the presented study was very narrow. Although the age range was 51-93 years, older participants prevailed (mean age 77.7 years) and only $6 \%$ of the respondents were younger than 65 years. Ageing must be understood as a positive, complex process, and old age as a phase of life that can be lived fully, with enjoyment and in good quality.

The effect of age on the domain Physical Health and Environment is mentioned in the Chinese study, where older participants had lower scores in the Physical Health domain, but higher in Environment, compared to younger participants. This could be caused by worse health in older respondents, but adequate living standards. ${ }^{7}$ Contrarily, a Finnish study did not confirm a correlation of age and the domain Physical Health, but showed a significant correlation between age and the domains Psychological, Social Relationships and Environment. ${ }^{8}$ Other studies confirmed the relation between increasing age and reduced QoL. ${ }^{25,26}$ However, some studies note that this effect on QoL is recorded only in the age category over 75 years. ${ }^{27}$ Halvorsrud presented that with an increasing age, people frequently suffer from various diseases and impairments which influence satisfaction with health and reduce QoL. ${ }^{28}$ Bryla also confirmed that age itself is not the determining factor, but in combination with other variables (illness, mental and physical disability) may significantly reduce QoL. ${ }^{17}$

The results of our research are limited by the size of the population sample in comparison to more extensive studies. ${ }^{7,12}$ That is why the results cannot be generalized for the entire Czech population of older adults.

\section{Conclusion}

The study results showed that nearly half of the respondents from the 2 Czech regions assessed QoL as good or very good and their satisfaction with health was most often neutral. Nevertheless, no significant correlation between the age of the respondents and the QoL assessment in particular domains of the WHOQOL-BREF questionnaire was demonstrated. Further, larger studies are needed to verify the influence of age on QoL in the particular domains dependent on the health status of the respondents, medication and social conditions amongst home care clients in the Czech Republic. 
The respondents from the Zlín and Uherské Hradiště regions in the presented study were least satisfied with their sex life. This shows that nurses have to take an active role in positively impacting the sexual health of this population. With appropriate education, nurses should acquaint the clients with the ways to overcome barriers in their sex life.

\section{References}

1. The Institute of Health Information and Statistics of the Czech Republic. Czech Health Statistics Yearbook 2013. $1^{\text {st }}$ ed. Prague: UZIS CZ; 2014.

2. Lucas-Carrasco R, Laidlaw K, Power M. Suitability of the WHOQOL-BREF and WHOQOL-OLD for Spanish older adults. Aging Ment Health. 2011; 15: 595-604.

3. Sewo Sampaio $P$, Ito $E$, Carvalho Sampaio R. The association of activity and participation with quality of life between Japanese older adults living in rural and urban areas. Journal of Clinical Gerontology \& Geriatrics. 2013; 4: 51-56.

4. Ma L, Li Y, Wang J, et al. Quality of life is related to social support in elderly osteoporosis patients in a Chinese population. PloS ONE. 2015; 10: e0127849.

5. Arslantas H, Adana, F, Abacigil Ergin, F, Kayar D, Acar G. Loneliness in elderly people, associated factors and its correlation with quality of life: A field study from western Turkey. Iran J Public Health. 2015; 44: 43-50.

6. Bodner E, Cohen-Fridel S, Yaretzky A. Sheltered housing or community dwelling: Quality of life and ageism among elderly people. Int Psychogeriatr. 2011; 23: 1197-1204.

7. Xia P, Li N, Hau K, Liu Ch, Lu Y. Quality of life of Chinese urban community residents: $A$ psychometric study of the mainland Chinese version of the WHOQOL-BREF. BMC Med Res Methodol. 2012; 12, 37.

8. Gott $M$, Hinchliff $S$. How important is sex in later life? The views of older people. Soc Sci Med. 2003; 56: 1617-1628.

9. Johnson J, Louhivuori J, Stewart A, Tolvanen A, Ross L, Era P. Quality of life (QOL) of older adult community choral singers in Finland. Int Psychogeriatr. 2013; 25: 1055-1064.

10. Lindau ST, Gavrilova N. Sex, health, and years of sexually active life gained due to good health: Evidence from two US population based cross sectional surveys of ageing. BMJ. 2010; 340: c810.

11. Liu N, Zeng L, Li Z, Wang J. Health-related quality of life and long-term care needs among elderly individuals living alone: A cross-sectional study in rural areas of Shaanxi Province, China. BMC Public Health. 2013; 13: 313.

12. Dragomirecká E, Bartoňová J. Quality of Life Questionnaire of the World Health Organization WHOQOL-BREF: Psychometric properties of a first experience with the Czech version [Dotazník kvality života Světové zdravotnické organizace WHOQOL-BREF: Psychometrické vlastnosti a první zkušenosti s českou verzí]. Psychiatrie. 2006; 10: 144-149.

13. Skevington S, Lotfy M, O'Connell K, WHOQOL Group. The World Health Organization's WHOQOL-BREF quality of life assessment: Psychometric properties and results of the international field trial: A Report from the WHOQOL Group. Qual Life Res. 2004; 13: 299-310.

14. Chachamovich E, Trentini C, Fleck M. Assessment of the psychometric performance of the WHOQOL-BREF instrument in a sample of Brazilian older adults. Int Psychogeriatr. 2007; 19: 635-646.

15. Hwang $\mathrm{H}$, Liang W, Chiu, Y, Lin M. Suitability of the WHOQOL-BREF for community-dwelling older people in Taiwan. Age Ageing. 2003; 32: 593-600.

16. Naumann V, Byrne, G. WHOQOL-BREF as a measure of quality of life in older patients with depression. Int Psychogeriatr. 2004; 16: 159-173.

17. Dragomirecká E, Prajsová J. User Manual. Czech version of questionnaires World Health Organization to measure quality of life in older age WHOQOL-OLD [Př́ručka pro uživatele české verze dotazníků Světové zdravotnické organizace pro měření kvality života ve vyšším věku WHOQOL-OLD]. $1^{\text {st }}$ ed. Prague: Psychiatrické centrum; 2009: 23-28.
18. Bryła M, Burzyńska M, Maniecka-Bryła I. Self-rated quality of life of city-dwelling elderly people benefitting from social help: Results of a cross-sectional study. Health Qual Life Outcomes. 2013; 11: 181.

19. Chao J, Lin Y, Ma C, et al. Relationship among sexual desire, sexual satisfaction, and quality of life in middle-aged and older adults. J Sex Marital Ther. 2011; 37: 386-403.

20. De Lamater J. Sexual expression in later life: A review and synthesis. J Sex Res. 2012; 49: 125-141.

21. Roney L, Kazer MW. Geriatric sexual experiences: The seniors tell all. Appl Nurs Res. 2015; 28: 254-256.

22. Chien C, Wang J, Yao G, Sheu C, Hsieh C. Development and validation of a WHOQOL-BREF Taiwanese audio player-assisted interview version for the elderly who use a spoken dialect. Qual Life Res. 2007; 16: 1375-1381.

23. Muhammad I, He HG, Koh K, Thompson DR, Kowitlawakul Y, Wang W. Health-related quality of life and its predictors among outpatients with coronary heart disease in Singapore. Appl Nurs Res. 2014; 27: 175-180.

24. Page KN, Davidson P, Edward K, et al. Recovering from an acute cardiac event: The relationship between depression and life satisfaction. J Clin Nurs. 2010; 19: 736-743.

25. Vitorino L, Paskulin L, Viana L. Quality of life among older adults resident in long-stay care facilities. Rev Lat Am Enfermagem. 2012; 20, 1186-1195.

26. Vitorino L, Paskulin L, Viana L. Quality of life of seniors living in the community and in long term care facilities: A comparative study. Rev Lat Am Enfermagem. 2013; 21: 3-11.

27. Netuveli G, Wiggins R, Hildon Z, Montgomery S, Blane D. Quality of life at older ages: Evidence from the English longitudinal study of aging (wave 1). J Epidemiol Community Health. 2006, 60, 357-363.

28. Halvorsrud L, Kirkevold M, Diseth A, Kalfoss M. Quality of life model: Predictors of quality of life among sick older adults. Res Theory Nurs Pract. 2010; 24: 241-259. 
